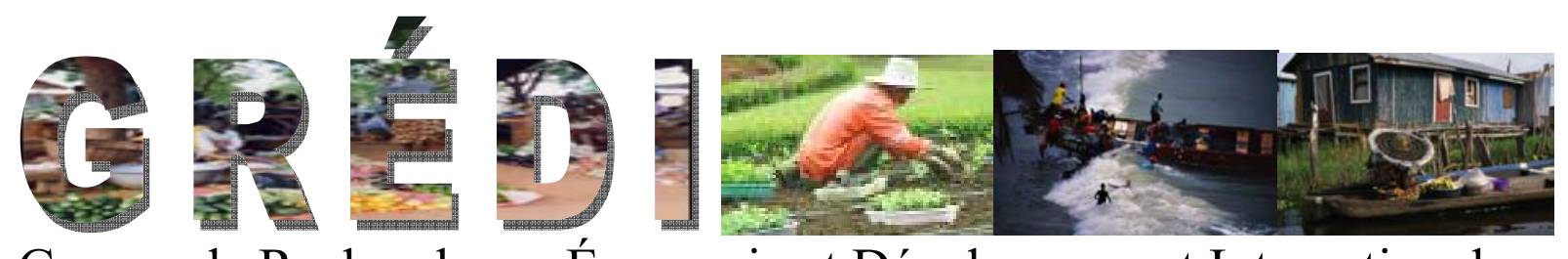

Groupe de Recherche en Économie et Développement International

\author{
Cahier de recherche / Working Paper \\ 08-07
}

Family migration: a vehicle of child morbidity in the informal
settlements of Nairobi city, Kenya?

Adama Konseiga 


\title{
Family migration: a vehicle of child morbidity in the informal settlements of Nairobi city, Kenya?
}

\author{
Adama Konseiga ${ }^{1}$
}

\begin{abstract}
$\underline{\text { Abstract }}$
Parental migration is often found to be negatively correlated with child health in Africa, yet the causal mechanisms are poorly understood. The paper uses a dataset that provides information from the respondent parent on child morbidity both in the rural and urban settings. Households first endogenously determine whether they will gain from participating in migration and, if they do, whether they will leave the children behind or not. The final choice is made to ensure the optimal survival chances for the child.

This paper contributes to understanding the health consequences of raising the children in the context of increasing urban poverty in Nairobi, Kenya. The findings indicate that households who migrated together with their children in the slums of Nairobi experience higher child morbidity (43 per cent have at least one sick child in the last one month) as compared to households who leave children in their upcountry homes (31 per cent of morbidity rate). Even though children of migrants are safer upcountry, not all households can afford this strategy. Households are able to choose this strategy only if they have a strong social support network in their origin community and/or they are big size households. This is an important finding in targeting the Millennium Development Goals.
\end{abstract}

Keywords: Childhood morbidity, Split migration, Incidental truncation, Informal settlements Nairobi, Kenya.

${ }^{1}$ Département d'Economique et Groupe de recherche en économie et développement international (GREDI). Faculté d'Administration. Université de Sherbrooke. Adama.Konseiga@,USherbrooke.ca 


\section{1- Introduction}

Currently ranked with the lowest level of urbanization, sub-Saharan Africa's urban population is however growing at a higher rate than any other region in the world. Its urban population was 15 percent in 1950, 32 percent in 1990, and is projected to be 54$60 \%$ percent by 2030 (United Nations 1998). While it is true that urban areas and cities offer the cost-reducing advantages of agglomeration economies and economies of scale and proximity as well as numerous economic and social externalities (e.g., skilled workers, cheap transport, social and cultural amenities), the social costs of a progressive overloading of housing and social services, not to mention increased crime, pollution, and congestion, tend gradually to outweigh these historical urban advantages especially in context where urban growth is not carried by economic expansion. The unprecedented growth of urban areas in the context of declining economic performance (World Bank 2000), poor planning and governance is actually creating a new face of poverty whereby a significant proportion of urban populations live below the poverty line in over-crowded slums and sprawling shanty towns in most African countries. It is estimated that about 72 per cent of all urban residents in sub-Saharan Africa live in informal settlements, commonly known as slums (UN-Habitat 2003).

In Kenya, with an urban population of about 34 per cent, about 71 percent of all urban dwellers are estimated to be living in informal settlements, which are characterized by extreme poverty, poor sanitation, inadequate social services, insecurity, social fragmentation, and poor livelihood opportunities. The situation is partly due to misguided urban-planning policies and outmoded building codes that often make $80-90 \%$ of new urban housings illegal (UN, 1991). Emerging evidence shows that, the traditional advantage that urban areas enjoyed in health and social indicators over their rural counterparts have either drastically dwindled or even reversed in favor of rural areas (Brockerhoff and Brennan 1998; Mugisha and Zulu, 2004; APHRC 2002; Dodoo, Sloan, and Zulu 2002). Between one and two million migrants reside in cramped conditions in the slums of the capital city Nairobi without proper access to sanitation or affordable clean water. Children in such areas are exposed to enormous risks, health risks in particular. For example, a large demographic and health focused survey conducted in various Nairobi slums in 2000 by the African Population and Health Research Center 
(APHRC) finds that not only are morbidity risks for all major childhood illnesses (fever, cough, diarrhea) higher for slum children compared to children elsewhere in Kenya, slum children also have less access to healthcare, including immunization, and subsequently face higher mortality rates than even their rural counterparts.

One coping strategy for slum dwellers is to adopt split migration where wife and children are secured in the home village while the head of household undertakes the income diversification and risk management project that is migration to Nairobi city. However this strategy is often impaired by the important monitoring costs that the migrant incurs to ensure that the spouse fulfills the ex-ante contract and does not divert the remittances into unproductive activities. The welfare implications of this information asymmetry are significant. Precious resources that could otherwise have been spent on, for example, healthcare or school fees, are spent on frequent costly traveling home. According to de Laat's estimations (de Laat, 2005) the average migrant couple visits each other at least 12.6 times per year, with the husband making the majority (at least 9.5) of the trips. The combined travel cost of these visits is $\$ 109$, or 11.1 per cent of his annual urban income. Some families for whom monitoring is simply too costly decide to move altogether to Nairobi, leaving children to be raised in precarious urban slum conditions, with obvious implications for children's health and general well-being. For example, the major change in the living environment has been shown to have a more negative impact on the grade progression of children migrating into large urban centers from rural communities than those moving from one rural community to another (Pribesh \& Downey 1999).

It's against this backdrop that the current study seeks to understand the contribution of migration in the urbanization of poverty and poor health in the two slums (Korogocho and Viwandani) where the Nairobi Health and Demographic Surveillance System (NUHDSS) is on-going. The paper focuses on the case of under-five children living in Nairobi and compares them to those living upcountry. The study sets to examine the motivations behind the choice of joint migration as compared to split strategy and the effect of the former migration strategy on child morbidity, after controlling for incidental truncation and other socioeconomic factors. The study hypothesis is that children born to joint migrants and exposed to the slum environment are more likely to fall sick than children born to split migrants because of the poor socio-economic situation, the poor 
environmental sanitation and the absence of alternative medical care in the slums. Slum settlements therefore expose children to high morbidity from preventable infectious diseases.

\section{2- Conceptual framework: Child morbidity and the choice of location}

\section{1-Child Health issues}

Health plays a dual role as input to the aggregate production function and output, which places it in the heart of the modern concept of economic development. Health is central to well-being, and essential for a satisfying and rewarding life. It is fundamental to the broader notion of expanded human capabilities as well as being able to participate and broaden choice. Health is prerequisite for increases in productivity and is certainly a precondition for a successful education, especially for children.

Health is usually measured using infant mortality rates and life expectancy. Life expectancy can be very misleading because it increase may mask additional years of suffering and poor health (Todaro and Smith, 2006). An alternative measure for the general well-being is the DALY: disability-adjusted life year. However measure based on DALY have so far faced a lot of data limitations. Child health remains one of the most popular development indicators because it measures the quality of life in developing countries pretty well.

The world as a whole experienced dramatic improvements over the past half century with under five mortality in developing countries decreasing from 280 deaths per 1000 live births in 1950 to 120 deaths per 1000 live births in the low-income countries. However the challenges remain huge compared to the level in the developed countries ( 7 deaths per 1000 live births). Each year, millions of life could be saved simply by treating diarrhea. Two billion of those who survive suffer malnutrition (lack of micronutrients) and infections. Every year, about 12 million of children under 5 die in developing countries. Because most of these children die of causes that could be prevented for just a few cents per child, it has been rightly claimed that their real underlying disease was poverty. In its 1993 report, the world bank estimated that one-quarter of the global burden 
of disease was represented by diarrhea, childhood diseases including measles, respiratory infections, parasitic worm infections, and malaria. Similarly the World Health Organization (WHO) has found that five conditions account for $70 \%$ of deaths among children under 5: acute respiratory infections, diarrhea, measles, malaria, and malnutrition.

Finally average health levels can mask great inequality, especially among special populations and infant mortality. Nairobi slum dwellers exhibit notably poor infant health outcomes (not less than 145 deaths per 1000 live births, which are above the current world average). It becomes therefore essential to assess the distribution of health and examine specific populations that are especially exposed to poverty and shed light to the root causes of child mortality toward the achievement of the Millennium Development Goals (MDG).

\section{1- Urbanization of poverty in Kenya}

Urban population growth in sub-Saharan Africa is principally driven by rural-urban migration of young adults seeking jobs and other livelihood opportunities in urban areas (Anderson 2001; Adepoju 1995). Given the increasingly poor living conditions and livelihood opportunities that are observed in most metropolitan centers in the region (Brockerhoff and Brennan 1998; World Bank 2000; APHRC 2002) it appears paradoxical that many rural residents continue to flock to urban areas. Classical migration theories portray migrants as rational economic agents moving to areas which maximize their incomes and overall well-being (Harris and Todaro 1970). In this long term endeavor, migrants account for their time horizon and probability of getting an employment, which explains why younger and more educated individuals are more likely to migrate. In Nairobi, for instance, attempts to move squatter residents to better and more expensive housing have had limited success. Many prefer to live in the relatively cheap squatter settlements in order to accumulate savings for various investments in their home communities while acquiring the city experience that prepares them for a more permanent formal urban job. This may explain the fact that the urban population growth rates have persisted at very high levels despite the sustained economic downturn experienced over 
the past two to three decades. The short run consequences are the growth of urban poverty and bad health performance, especially in the informal settlements.

Despite the fall in employment opportunities associated with the economic downturn in Kenya from the 1980s, Nairobi's population continued to grow at about 5 per cent per year between 1969 and 1999 (Agwanda et al. 2004; Government of Kenya 2000). The city's population is principally composed of migrants; the proportion of cityborn residents is no more than 20 per cent up to age 35 and less than 10 per cent after age 50. Half of the migrants came to Nairobi between 17 and 23 years old (Agwanda et al. 2004). In this context, income differentials between rural home and urban settlement and remittances cannot be the sole motivation for migration. The next section proposes an alternative mechanism.

\section{3- Relationships between child morbidity and physical environment}

Parental migration is often found to be negatively correlated with child health in Africa, yet the causal mechanisms are poorly understood. The main argument in this paper is to assume that the health environment is an endogenous choice. Unlike previous works, I assume that households first endogenously determine whether they will gain from participating in migration and, if they do, whether they will leave the children behind. The final choice is rationally made to ensure the optimal survival chances for the child.

A basic specification of the resulting reduced form child health output can be based on Glewwe (1999). Child health depends on variable inputs such as Health and nutritional inputs, and some shifters (the environment and a child's health endowment).

$$
H_{i}=f\left(H I_{i} ; \mathrm{E}_{\mathrm{i}}, \varepsilon_{\mathrm{i}}\right)
$$

where $H_{i}$ is the health of child $i, H I_{i}$ is a vector of health inputs chosen by child $i$ 's household, $E_{i}$ is a vector summarizing the environmental conditions surrounding child $i$, and $\varepsilon_{i}$ is the child's genetic health endowment.

However even though in optimizing child health the household ultimately makes decision on his allocations of health and nutritional inputs (prenatal care, breast milk, medicines, and medical care etc.); it is clear that the environment is also his own 
endogenous choice at some extent. Survey data collected in two of Nairobi's informal settlement areas in 2004 indicated that among married migrants 48 percent were classified as split migrants, and the remaining 52 percent as joint migrants.

At a first stage the household is confronted with the decision choice about where he wants his child to grow up with the optimal survival chances. In particular, most households in the surveillance slums compare the slum health environment with the place of origin upcountry. The split migration that generally suggests leaving the mother and children upcountry increases the amount of time the mother works at household rural farm. Increased time of the mother at home has a direct positive impact on child health.

Given the national amenities and health facilities policy biased toward formal sector, health related reasons actually appear as the least important reasons $(0.36$ per cent) attracting rural residents into the slums. In comparison, it is a more important factor pushing slum residents to move back to the rural parts of Kenya (3.05 per cent). ${ }^{2}$ Even though the latter evidence encompasses the older people and terminal ill HIV/AIDS affected people, it clearly suggests that health outcomes are not in general neutral to location choice. As pointed out in de Laat and Archambault (2007), large urban inequities exist in Nairobi, and among the urban poor, the advantages of urban social amenities and public services are questionable. Parents use perceptions of urban-rural differences in social amenities to carefully weigh concerns about child well-being when deciding whether to embark on family migration. This helps explain why more than half of all children to married migrant men in the Nairobi slums are not living in Nairobi.

For slum residents aged 15 years and above by end of 2004, NUHDSS data also show that family related reasons (especially for female), better job prospects and lower cost are the most important reasons why people across all ages move into the Demographic Surveillance System $(\mathrm{DSA})^{3}$. It is important to remember that these responses are the ex-ante perceptions of the migrants. However for out-migration that occurs following the slums experience, Figure 1 shows that family reasons are the most

\footnotetext{
${ }^{2}$ Figures are estimated from the livelihood survey conducted in May 2003 in Korogocho and Viwandani.

${ }^{3}$ The reasons for in-migration into the DSA were recoded into five categories namely: family related reasons which include marriage, moving with the family; and moving to live near relatives; better amenities and social services which include housing and health related attributes; better job prospects; lower cost; and other reasons
} 
important reasons among female out-migrants; while among males poor job prospects are the most important together with poor amenities and social services (including health reasons). Among older individuals $(60+)$, health related reasons are among the most important factors that determine their migration out of the DSA.

Additionally de Laat and Archambault (2007) also found that security was Nairobi main disadvantage, including the risk to children's health when living in the slums. Even though many people believed that the availability of health facilities was better than the ones in their rural homes, the daily health risks to children living in the slums were perceived by most as much higher. Slums are characterized by polluted rivers, lack of sewers, sanitation facilities, and garbage pick-up, thus exposing children to greater health risks. Almost all exposed residents have unfavorable views of the Nairobi environment.

Finally, a rural migration into the urban slums is a major environmental change for all members of the migrant household but more so for the children (negative impact on the grade progression of children as well as their psychological and health development).

Fig. 1: Reason for out-migration by sex

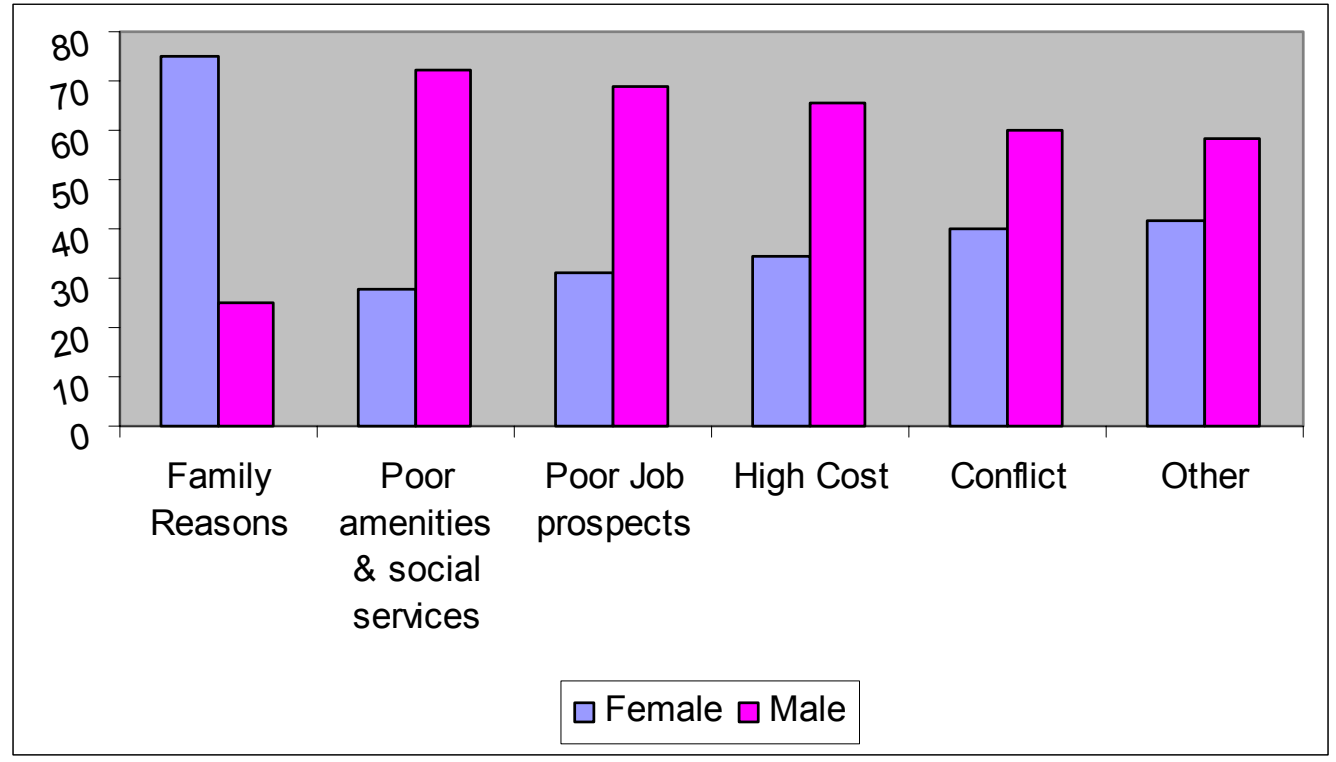




\section{3- Data and statistical methods}

\subsection{Study site and data collection}

The following analysis is based on the 2004 Nairobi Informal Settlement Survey (2004 NIS) that collected data in two of Nairobi's slums, Korogocho and Viwandani (de Laat, 2004). The survey was conducted between 04 May 2004 and 27 June 2004 on a subsample in these two communities where the NUHDSS operates ${ }^{4}$. Eligibility was defined as being "ever married" and between the ages of 24 and 56 years old. The primary objective of this research project was to look at health and education of children whose parents live in the Nairobi informal settlements (Korogocho and Viwandani).

The survey randomly selected 1817 'eligible' heads of households i.e. (1) heads of households who are divorced or separated (153 in total), or widowed (150); heads of households who are married and live with their spouse together in the Nairobi informal settlement (858 joint migrants in total); or heads of households who are married but live split from their spouses who usually live in the up-country village (656 split migrants in total). There was no stratification by informal settlement area. A total of 37 household heads refused to participate in the NIS 2004, which represents only $2 \%$ of the initial sample. The most comprehensive survey questionnaire is that for the category of married household heads that live split from their spouse. The survey also contains relatively detailed information about family members who are not members of the household being interviewed. The following information is recorded in the database:

- $\quad$ All variables at household level, including consumption.

- $\quad$ All variables related to members of the household who are living in the Nairobi slums.

- All variables related to the spouse(s) of the household head (called spousal household).

\footnotetext{
${ }^{4}$ APHRC is conducting an extensive Health and Demographic Surveillance System (NUHDSS), which served as sampling frame for the NIS survey. The data collection procedures of the NUHDSS include visits to all 23,000 households in the Demographic Surveillance Area (DSA) every four months to update information on all vital events (birth, deaths, movements, vaccinations and pregnancies). Movements include change of residence and migrations.
} 
The current paper focuses on the health of children whose parents are currently married. It is assumed that the groups of widowed, divorced, separated households are independent from the study groups and they can be left out. Two groups of households are then considered: household heads who live in the slums with their spouse(s) and children and those who keep the whole family upcountry (eligible control group). Thereafter these groups are referred to respectively as joint migrants and split migrants.

It appears that the survey does not cover non-eligible unmarried groups, especially those who are not observed in the risk set of the DSA. However the survey included an additional module called spouses household roster that collected information about split migrant's spouse and children who are not observed in the slums.

The statistical challenge can be described as followed. The current study disposes of a final dataset with 1514 observations on migration living arrangements outcomes (migration type) in Viwandani and Korogocho. I have full data (no missing values) for all the covariates in the morbidity and migration type participation functions. With the latter information, I want to estimate a child morbidity function. This estimation needs to be corrected for selection into the DSA as split or joint migrant. The problem can be summarized by considering the data on:

- "Split" sub sample: heads of households who are married but live split from their spouses who usually live in the up-country village (656 in total) ${ }^{5}$.

- "Joint" sub sample: heads of households who are married and live with their spouse together in the Nairobi informal settlement (858 in total);

While the outcomes of the joint children are observed, "split children" morbidity data are not observed in the same slum conditions and are obviously missing for the slum structural model. This entails a problem of incidental truncation that can be resolved using the Heckman model. The latter consists in using sample ("Joint+Split") to estimate the migration selection model and then uses sub sample "Joint" to estimate the children morbidity equation.

\footnotetext{
${ }^{5}$ In fact this group is reduced to 652 cases of split migrants who have information on their spouse upcountry.
} 


\subsection{Econometric model}

While some studies ask about the health and education of children, these studies often do not recognize that while some people have their whole family in the urban slums, many others have children and spouses living upcountry. The importance of split migration has not been much studied in the migration literature. Typically split migrants are married heads of households who adopt a temporary move and live split from their spouses (who usually live in the up-country village with the children). This allows protecting the children's health from the poor environmental conditions of the destination place. The objective of this section is to analyze the NIS data to understand why some parents have their children in the slums and others do not, and what the effects are for the wellbeing of the children. The findings may suggest relevant policies that may improve the lives of poor people living in cities in line with the Millennium Development Goals.

Precisely the relationship between migration strategy and child health among slum residents is estimated. First, I focus on describing the changes in child morbidity across migration type. Second, the study estimates an econometric model and further investigates whether migration impact on child health is different across gender.

Slum dwellers are an important group to study because they are highly mobile (inand out-migration rates describe a circular migration, in particular between rural and urban places) and exhibit notably poor infant health outcomes (not less than 145 deaths per 1000 live births, which is above the current world average). In the study sample, 62.81 percent have at least one child (951 households) and among them 43 percent have left their children upcountry. The relevant sample for the current study is therefore composed of 557 joint households against 397 split households. The latter sample distribution suggests that 43 percent of the households who have children consider the migration project more beneficial if they leave children upcountry according to the theory. Analyzing the behavior of split migrant households from a population leads to incidental truncation problem because these migrants are a restricted nonrandom part of an entire population. The households that supply migrants' labor may possess unobserved characteristics that are generally positively related to the health and income, which result 
in a sample selection bias. With such a distortion, results from a standard Ordinary Least Squares (OLS) are simply biased. The regression model that includes the above selection issue is the migration model à la Nakosteen and Zimmer (1980). The simultaneous system writes:

Net benefit of moving:

$$
V_{i}^{*}=\alpha Z_{i}+\gamma^{\prime} X_{i}+\varepsilon_{i}
$$

Children morbidity outcomes of joint migrant households:

$$
\log m O_{j i}=\beta_{j}^{\prime} X_{j i}+\mu_{j i}
$$

and children morbidity outcomes of split migrant households:

$$
\log m O_{s i}=\beta_{s}^{\prime} X_{s h i}+\mu_{s i}
$$

To estimate the simultaneous migration type decision and child morbidity equations, it is assumed that $V_{i}{ }^{*}$ and $\log m o_{i}$ have a bivariate normal distribution with correlation $\rho$. An analysis of morbidity in either sub-sample must account first for the structural differences of health and production markets in the related locations (slums and upcountry) and for the incidental truncation of the split's (joint's) morbidity on the sign of the net benefit. To face estimation problems of a model with sample selection, a Heckman two-step procedure is used for the study of joint migration. In this case, outputs are interpreted with split migrants as the reference category. The Heckman regression model adapted to the current situation where the outcome variable is binary can be written for the selected sample as in equations (1)' and (2-3)' below.

Selection model:

$P_{i}^{*}=\alpha Z_{i}+\gamma^{\prime} X_{i}+\varepsilon_{i}$

Where $\boldsymbol{P}^{*}$ is the probability of the variable indicator of the sign of the selection criteria that is the net benefit from joint migration. $\boldsymbol{Z}_{\boldsymbol{i}}$ and $\boldsymbol{X}_{\boldsymbol{i}}$ represent the independent variables of the selection equation identification and those of the morbidity equation respectively.

Morbidity model: 
$\log m o_{i}=\beta^{\prime} X_{i}+\beta_{\lambda} \lambda_{i}+\nu_{i}$

Where the following relationship exists between the coefficient of the inverse Mills' ratio $\lambda$ and the model statistics: $\beta_{\lambda}=\rho_{\sigma_{\mu}}$. The inverse Mills' ratio (IMR) itself evaluates as the ratio of the probability and cumulative density functions from the selection equation. Heckman (1979) argues that this function is a monotone decreasing function of the probability that an observation is selected into the analyzed sample.

The Heckman's two-step estimation procedure is applied to the selected group of joint migrants taking into account the fact that joint migrants and split migrants face distinct labor and production market structure respectively in their rural homes and in the slums. The probit equation (1)' is estimated to obtain estimates of $\alpha$ and $\gamma$ and compute the inverse Mills' ratio. At a second step of the Heckman procedure, the inverse Mills' ratio is added to the child morbidity outcomes equation (2-3)' to produce the consistent estimates of $\beta$ and $\beta_{\lambda}$. However, the coefficients estimated in equation (1)' (respectively (2-3)') measure how the log-odds in favor of migrating (respectively falling sick) change as the independent variables change by a unit. For the correct interpretation of these nonlinear outcomes, marginal effects should then be computed (Long and Freese 2001).

\subsection{Model variables and estimation}

The health child outcome depends on household characteristics, local community environment and child endowment. This leads to the following principal variables:

- Household initial assets (toilet, water), parental education.

- The health and education facilities in the community (social amenities, availability and accessibility of health services, parasites, contagious illnesses)

- and the child genetic endowment

In this paper, child health status is quantified using self-reported morbidity data. Because of all problems related to such data, we need to explain in details the outcome variable being used. 


\section{The morbidity variable and reliability issues}

Although there is an important literature addressing migration and assimilation processes for understanding health differences, most suffer from a common limitation: they are based on data from the destination area (Landale and Oropesa, 2001). Even though the current study data does not make exception to that problem, this is a rich survey that tried to overcome the aforementioned limitation. The dependent variable is an indicator of whether the household had a child who was sick in the month preceding the NIS 2004 survey or not.

Typically, the main weakness of previous studies is that they are based on the same population at risk (located in the slums). These studies compare outcome within a quite homogenous group across generations of residence or according to duration of residence in the destination place. While such comparisons provide useful information (Zulu, Konseiga, Darteh, and Mberu 2006), the evaluation of arguments stressing migration-related processes requires that migrants be compared with non-migrants in the origin place. This is the emphasis of the present study.

Comparing self-reported morbidity with indicators of morbidity from physicians' evaluations, Ferraro and Farmer (1999) found that self-reported morbidity is equal or superior to physician-evaluated morbidity in a prognostic sense. When data from respondents and physicians do not agree, the presumption is that respondents are underreporting or overreporting medical conditions. However the study suggests that biopsy or autopsy may be the gold standard. The study suggests that self-reported data should not axiomatically be characterized as inferior solely because they come from respondents. The accuracy of survey data remains an empirical question. Most of the time responses from survey participants are likely to be biased by the assumptions that the respondents apply to the problem. The type of information collected and the context of the questioning are also important when attempting to understand discrepancies between self-reported data and other information sources. For instance, questions regarding sexually transmitted diseases probably contain more bias than would be the case for other conditions such as heart attack or the child health. 
It remains that the data collected on self reported morbidity outcomes, especially for children staying upcountry may have some measurement errors. This may not be a major problem as morbidity is the primary dependent variable of interest. Indeed, traditionally measurement error in an explanatory variable has been considered a much more important problem than measurement error in the response variable (Wooldridge, 2002). In addition even though self-reporting may be a mis-measure of actual children health, it remains that all economic decisions (for instance decision to return upcountry or to regroup the family in one place) by the household head are conditioned by his perceptions of child wellbeing upcountry relatively to children in the slums. When estimating a linear equation with measurement error in the dependent variable under OLS conditions, what is important is how the error is related to other factors (Wooldridge, 2002). We can ignore the fact that the dependent variable is an imperfect measure and obtain consistent estimators of the regression parameters if the measurement error is statistically independent of each explanatory variable. In this context, the measurement error may only affect the intercept if the former does not have zero mean. However we may assume that the measurement error is not independent of the migration status. Even in the latter scenario where the split head of household may underreport sickness of his children upcountry due to lack of contact ${ }^{6}$, the consequences are that the error term is negatively correlated with migration status. The correction for the downward bias in the split migration parameter involves instrumental variables estimation, which is done in the Heckman procedure used below.

In the current study, specific attempts to control for the measurement bias did not show any significant evidence of information bias on reporting sickness upcountry versus urban location. The respondent bias was captured as an indicator of household head who did not know about sickness status of his children living upcountry (missing, refusal or don't know as response) but knew the morbidity status of his members in the slums.

\footnotetext{
${ }^{6}$ This seems unlikely. Recall that at least 11 percent of the urban annual income is spent on frequent travels upcountry, not including the phone communications.
} 
Table 1: The distribution of the study participants according to the migration status and the age of the slum households

\begin{tabular}{|c|c|c|c|c|c|c|c|}
\hline & & $\begin{array}{l}\text { Survey sample } \\
\text { (household) }\end{array}$ & & $\begin{array}{l}\text { Household with } \\
\text { Children (estimation } \\
\text { sample) }\end{array}$ & & $\begin{array}{l}\text { Child morbidity } \\
\text { prevalence } \\
\text { (household level) }\end{array}$ & \\
\hline & & $\mathbf{N}$ & $\%$ & & $\%$ & $\mathbf{N}$ & $\%$ \\
\hline \multirow{5}{*}{$\begin{array}{l}\text { Total } \\
\text { Joint }\end{array}$} & & 1,514 & & 951 & & 951 & \\
\hline & NIS 2004 & 858 & $57 \%$ & 557 & $59 \%$ & 241 & $43 \%$ \\
\hline & Viwandani & 470 & $31 \%$ & 294 & $31 \%$ & 117 & $40 \%$ \\
\hline & Korogocho & 82 & $5 \%$ & 49 & $5 \%$ & 20 & $41 \%$ \\
\hline & Nyayo & 306 & $20 \%$ & 214 & $23 \%$ & 104 & $49 \%$ \\
\hline \multicolumn{8}{|l|}{ Split } \\
\hline & NIS 2004 & 656 & $43 \%$ & 397 & $42 \%$ & 125 & $31 \%$ \\
\hline & Viwandani & 497 & $33 \%$ & 311 & $33 \%$ & 90 & \\
\hline & Korogocho & 33 & $2 \%$ & $\begin{array}{l}14 \\
72\end{array}$ & $1 \%$ & 3 & $\begin{array}{l}21 \% \\
44 \%\end{array}$ \\
\hline \multirow[t]{6}{*}{ Age } & Nyayo & 945 & $62 \%$ & 945 & 070 & & \\
\hline & 0 year & 97 & $6 \%$ & 97 & $10 \%$ & & \\
\hline & 1 year & 190 & $13 \%$ & 190 & $20 \%$ & & \\
\hline & 2 year & 325 & $21 \%$ & 325 & $34 \%$ & & \\
\hline & 3 year & 194 & $13 \%$ & 194 & $21 \%$ & & \\
\hline & 4 year & 139 & $9 \%$ & 139 & $15 \%$ & & \\
\hline
\end{tabular}

Source: Author estimations based on NIS 2004

Notes: Korogocho includes Nyayo in the definition of the NUHDSS

Note: 9 households ( 3 in Nyayo and 6 in Viwandani) have children both in the urban and rural places. This may be an interesting strategy where split household head takes to Nairobi the older or most healthy children.

Table 1 shows that while only 31 per cent of split household had an under-five child who was sick last month, about 44 per cent of joint migrants had a child exposed in the slums who suffered illness. 61 per cent of all split households have children underfive years old who live upcountry ("split children"). The proportion in the urban or joint households group who has under-five children is 64 per cent. This suggests the two groups of the study population are comparable in terms of their fertility rates.

Table 2 shows the total morbidity rate in the two slums of Nairobi at individual level, that is, $23.22 \%$ for the whole population. However child morbidity reaches the important level of $39 \%$ in 2004 . There appears no significant difference between male and female of the study population as regards under-five morbidity. However, under-five children in the slums tend to be sicker than their rural counterparts and even so for girls (7 percentage points difference). 
Table 2: Gender and morbidity profile in the slums and upcountry (individual level)

\begin{tabular}{|c|c|c|c|c|c|c|}
\hline $\begin{array}{l}\text { Urban } \\
\text { population }\end{array}$ & & \multicolumn{2}{|l|}{5,733} & \multicolumn{2}{|c|}{$\begin{array}{l}\text { Under-five } \\
\text { urban } \\
\text { population }\end{array}$} & 865 \\
\hline \multirow{9}{*}{$\begin{array}{l}\text { Upcountry } \\
\text { population }\end{array}$} & Male & 3,165 & $55 \%$ & Male & 420 & $49 \%$ \\
\hline & $\begin{array}{l}\text { Male- } \\
\text { sick }\end{array}$ & 737 & $13 \%$ & Male-sick & 164 & $19 \%$ \\
\hline & Female & 2,568 & $45 \%$ & Female & 445 & $51 \%$ \\
\hline & $\begin{array}{l}\text { Female- } \\
\text { sick }\end{array}$ & 594 & $10 \%$ & $\begin{array}{l}\text { Female- } \\
\text { sick }\end{array}$ & 173 & $20 \%$ \\
\hline & & 2,773 & & $\begin{array}{l}\text { Under-fiv } \\
\text { populatiol } \\
\text { upcountry }\end{array}$ & & 531 \\
\hline & Male & 1,144 & $41 \%$ & Male & 293 & $55 \%$ \\
\hline & $\begin{array}{l}\text { Male- } \\
\text { sick }\end{array}$ & 214 & $8 \%$ & Male-sick & 75 & $14 \%$ \\
\hline & Female & 1,629 & $59 \%$ & Female & 238 & $45 \%$ \\
\hline & $\begin{array}{l}\text { Eemale- } \\
\text { sick }\end{array}$ & 297 & $11 \%$ & $\begin{array}{l}\text { Female- } \\
\text { sick }\end{array}$ & 71 & $13 \%$ \\
\hline
\end{tabular}

Source: Author estimations based on NIS 2004

\section{Empirical results}

The covariates used in the Heckman model to identify the selection equation and explain morbidity outcomes in the slums are summarized in table A1 (see Appendix) and include:

- Selection variable

- Migration status (joint versus split migration)

- Control Variables

- Age of the children, average educational attainment of the household, literacy of the household head in the urban settlement, religion, gender of the household head, orphan status, ethnicity, total size of the household, care giver, social network in the origin place, the wealth index, production factors (land and labor) and location of the urban head.

This section implements the econometric analysis and interprets successively the reduced form of the migration type selection and the morbidity outcome model. The latter evaluates the impact of the covariates corrected for selection bias.

Table 3 indicates that the bivariate effect of choosing the joint migration strategy is significantly high. The risk of having a child to fall sick is 39.2 per cent higher in the slums than in the home rural place. 
Table 3: Morbidity of slum children in joint/split household

\begin{tabular}{lc}
\hline Explanatory variables & Sick last month \\
\hline & \\
\hline married under joint migration & $0.331 * * *$ \\
& $(3.90)$ \\
Constant & $-0.482^{* * *}$ \\
& $(-7.35)$ \\
Observations & 945 \\
Log Likelihood & -623.2 \\
\hline \multicolumn{2}{c}{$\mathrm{z}$ statistics in parentheses } \\
& $* * * \mathrm{p}<0.01, * * \mathrm{p}<0.05, * \mathrm{p}<0.1$
\end{tabular}

A more elaborate estimation that controls for selection bias and other covariates follows in table 4 . The results in the outcome model (regression 1 in table 4) support that the child morbidity of joint migrant households in the slums of Nairobi is a positive function of the schooling capital in the household but negatively depend on the education level of the head of household as compared to the reference group of split migrant. This suggests two different findings. First, the average level of education of the urban household plays against the health of children. This is explained by the fact that educated adults tend to leave children with care-givers while at work. In the poor sanitation conditions of the slums, it is the younger children who suffered most (negative sign of age of under-five children). In particular educated spouses or female heads of household spend more time in the urban labor market and therefore spend less time in reproduction activities (less breastfeeding for example). Additionally the presence of the educated head (urban joint migration) is very important for the health of children. Children born to educated household heads who stay far from the family may be sicker. In the case of missing or imperfect labor market, the household must rely on the family labor and thus sending a household member (the head in this case) may also stop the household from moving toward the local high-return activity (farm and health productions). The adverse effect of lost labor may be higher when migrants tend to be younger and better educated than an average rural laborer.

Similarly the regression shows that father-orphan's children who are raised in the conditions of the slums suffered more diseases than others.

Children born to a protestant family appears to be less sick than children from the other religious groups. Even though the effect is not significant, this may suggest that the protestant social network and level of cooperation work better in the conditions of the 
city life. On the opposite being from a Luhya family exposed children to higher health risk as compared to other ethnic groups such as Kikuyu.

The likelihood of the household to migrate jointly (selection equation number 2 in table 4) is significantly dependent on medium size of social network, the wealth index and the availability of agricultural factors. Compared to households who know 1 to 10 people in their origin community upcountry, households who know between 11 and 30 people are more likely to choose split migration. The social network literature argues that knowing more people enables the departure of the migrant. In the 2004 NIS survey, it is found that monitoring cost in terms of controlling the work effort and investment behavior of the spouse is very high (at least 11 percent of the urban annual income is spent on frequent travels upcountry). The most frequent and costly monitoring mechanism is frequent travels upcountry and the split migrant can substitute this by delegating some monitoring activities to his relatives left behind. One explanation of the advantaged health status of the upcountry resident also emphasizes the role of origin cultures in fostering family cohesion and the provision of social support. Because close friends and family members often encourage health-promoting behavior, especially by being a first source of information through their child care experiences, social support may play an important role in the positive health practices and outcomes of those staying upcountry as compared with slum migrants.

Finally households who are better endowed with production factors (land) or are richer (own houses in Nairobi) are those who can afford the split migration, leaving the family members to work on the agricultural farms while being able to face important monitoring costs. 
Table 4: Morbidity of slum children in joint/split household

\begin{tabular}{|c|c|c|}
\hline Covariates & $\begin{array}{c}\text { (1) } \\
\text { Sick last month }\end{array}$ & $\begin{array}{c}(2) \\
\text { Joint } \\
\text { migrant } \\
\end{array}$ \\
\hline Average Years of schooling of the household & $\begin{array}{c}0.0519^{* *} \\
(2.14)\end{array}$ & \\
\hline Average age of the under 5 & $\begin{array}{c}-0.0640 \\
(-1.34)\end{array}$ & \\
\hline Religion $==$ Protestant & $\begin{array}{l}-0.122 \\
(-1.09)\end{array}$ & \\
\hline Urban head is literate $==$ Yes & $\begin{array}{c}-0.781^{*} \\
(-1.75)\end{array}$ & \\
\hline Has lost father in the last 10 years & $\begin{array}{c}0.264 * * \\
(2.19)\end{array}$ & \\
\hline Female household head & $\begin{array}{c}0.465^{* *} * \\
(2.35)\end{array}$ & \\
\hline Ethnicity==Luhya & $\begin{array}{c}0.328 * * \\
(2.11)\end{array}$ & \\
\hline Slum $==$ Nyayo & $\begin{array}{l}0.172 \\
(1.45)\end{array}$ & \\
\hline Social network from origin community $==0$ & & $\begin{array}{c}0.0396 \\
(0.30)\end{array}$ \\
\hline Social network from origin community $==11-30$ & & $\begin{array}{c}-0.343 * * * \\
(-3.21)\end{array}$ \\
\hline Social network from origin community $==31-50$ & & $\begin{array}{c}0.00173 \\
(0.011)\end{array}$ \\
\hline Social network from origin community $==50+$ & & $\begin{array}{l}-0.0132 \\
(-0.082)\end{array}$ \\
\hline Members in spousal+urban household & & $\begin{array}{c}-0.201 * * * \\
(-8.62)\end{array}$ \\
\hline Own land/houses in Nairobi & & $\begin{array}{c}-0.0481 * * \\
(-2.30)\end{array}$ \\
\hline Available agricultural production factors & & $\begin{array}{c}0.00811^{* *} \\
(2.18)\end{array}$ \\
\hline & 0.108 & $1.299 * * *$ \\
\hline & $(0.20)$ & $(9.72)$ \\
\hline & 946 & 946 \\
\hline & -955.9 & \\
\hline
\end{tabular}

$\mathrm{z}$ statistics in parentheses

$* * * \mathrm{p}<0.01, * * \mathrm{p}<0.05, * \mathrm{p}<0.1$

LR test of indep. eqns. $($ rho $=0): \quad \operatorname{chi} 2(1)=0.15$ Prob $>$ chi $2=0.6978$

The robustness of the results is tested against a treatment effects model specification. According to the latter, migration has merely an intercept effect on child morbidity; then the appropriate model includes migration status as a right-hand side variable, and pools the entire sample of joint and split migrant households. The treatment effects model is then supposed to measure the migration project effectiveness. The results 
in table A4 (Appendix) support that the effect of migration does not show up as a dummy variable. This suggests that the results in table 4 above are more robust and therefore the constant term and other coefficients of the child morbidity model are different in both sub-samples of joint migration and split migration.

However it remains important to compare the current findings with data collected using alternative forms of measuring child health such as using anthropometry or biomarkers to measure nutritional status for children and mothers or using World Health Organization (WHO) and other quality of life measurements for child and adult health focused on disability, mental health, etc.

\section{Conclusion}

To provide better education and health services to everyone as required by the Millennium Development Goals (MDGs), it is important to understand why some parents have their children in the slums and others do not, and what the effects are for the children.

The present study examines the joint migration of the whole family in the slums of Nairobi and estimated the effect of such strategy on child morbidity. On the one hand, it appears that the likelihood of the household to migrate jointly is significantly higher for households with poor social networks in their origin community, which makes it impossible for the household head to face the high monitoring (especially travel) cost related to the split migration. Households who are better endowed with land or are richer (own houses in Nairobi) are also those who can afford the split migration, leaving the family members to work on the agricultural farms while being able to face important monitoring costs.

The findings indicate that the bivariate effect of choosing the joint migration strategy is significantly high. The risk of falling sick for a child is 39.2 per cent higher in the slums than in the home rural place. The results also support that the morbidity of joint migrant households in the slums of Nairobi negatively depends on the education level of the head of household as compared to the reference group of split migrant. This suggests that the presence of the educated head is very important for the health of children. 
Children born to an educated household head that stays far from the family may be sicker. In the case of missing or imperfect labor market, the household must rely on the family labor and thus sending a household member (the head in this case) may also prevent the household from moving toward the local high-return activity (farm and health productions). The adverse effect of lost labor may be higher when migrants tend to be younger and better educated than an average rural laborer.

Finally the research indicated that in the poor sanitation conditions of the slums, it is the younger children who suffered most especially when the adults (the mother) allocate time away from home in the urban labor market. Similarly children who lost their father but are raised in the conditions of the slums suffered more diseases than others.

The study suggests several ways to ensure better health of the slum children through the promotion of the split migration strategy or the welfare compensation of losers who are identified as the children in the slums. A constructive urban policy is necessary to realize the potential of cities to foster successful development, while at the same time giving more balanced treatment to development in rural areas so that to avoid the urban bias. These findings can be validated using the rich longitudinal data collected by the NUHDSS which unlike the cross-sectional NIS survey may allow studying the time dimension and vulnerability through monitoring changes in health status of the urban poor.

\section{ACKNOWLEDGEMENTS}

I am grateful to Joost de Laat who made this data available and to the African Population and Health Research Center in Nairobi for their support in understanding the complex setting of the Nairobi Urban and Health Demographic Surveillance System (NUHDSS).

\section{REFERENCES}

Adepoju, J. (1995) "Emigration Dynamics in sub-Saharan Africa", International Migration. Special Issue: Emigration Dynamics in Developing Countries, 33 (3/4).

Agwanda, A.O., Bocquier, P., Khasakhala, A., and Owuor, S.O. (2004) "The effect of economic crisis on youth precariousness in Nairobi: An analysis of itinerary to adulthood of three generations of men and women", DIAL Working Papers / Documents de Travail. 
2004(DT/2004/4):32 p. http://www.dial.prd.fr/dial_publications/PDF/Doc_travail/200309.pdf.

Anderson, J.A. (2001) "Mobile workers, urban employment and 'rural' identities: rural-urban networks of Buhera migrants, Zimbabwe", in M. Dedruijn, R. Van Dijk and Dick Foeken (eds.), Mobile Africa: Changing Patterns of Movement in Africa and Beyond, Lieden, the Netherlands: Brill.

APHRC. (2002) "Population and health dynamics in Nairobi Informal Settlements", Nairobi Kenya: African Population and Health Research Center (APHRC).

Bardhan, P., and C. Udry (1999) Development Microeconomics, Oxford: Oxford University Press, 236p.

Brockerhoff, M. and Ellen Brennan (1998) "The poverty of cities in developing Countries", Population and Development Review 24(1): 75-114.

de Laat J. and C. Archambault (2007) "Child Well-Being, Social Amenities, and Imperfect Information: Shedding Light on Family Migration to Urban Slums", PAA, New York city.

de Laat, Joost (2005) "Moral Hazard and Costly Monitoring: The Case of Split Migrants in Kenya", Job Market Paper, Brown Un.

de Laat, Joost (2004) “2004 Nairobi Informal Settlement Survey”, Brown Un. / APHRC, 2004

Dodoo, F.N., Sloan, M. and Zulu, E.M. (2002) "Space, context, and hardship: Socializing children into sexual activity in Kenyan slums", in Samuel Agyei Mensah and John B. Ferraro K. F. and M. M. Farmer (eds) Utility of Health Data from Social Surveys: Is There a Gold Standard for Measuring Morbidity? American Sociological Review, Vol. 64, No. 2. pp. 303-315.

Glewwe P. (1999) "Why Does Mother's Schooling Raise Child Health in Developing Countries? Evidence from Morocco", The Journal of Human Resources, 34(1): 124-159.

Government of Kenya (2000) Second Report on Poverty in Kenya - Volume I: Incidence and Depth of Poverty, Nairobi: Central Bureau of Statistics, Ministry of Planning and National Development. http://www4.worldbank.org/afr/poverty/pdf/docnav/02880.pdf

Harris, J.R. and Todaro, M. P. (1970) "Migration, unemployment and development: A two sector analysis", American Economic Review, 60(1): 126-42.

Heckman, J. J. (1979) “Sample Selection Bias as a Specification Error”, Econometrica, 47(1): 153-161. 
Johnston, A.E. and W.E. Whitelow (1974) "Urban-rural income transfers in Kenya: An estimated remittances function", Economic Development and Cultural Changes, 22(3): 473-79.

Landale N. S. and R. S. Oropesa (2001) "Migration, Social Support and Perinatal Health: An Origin-Destination Analysis of Puerto Rican Women”, Journal of Health and Social Behavior, 42(2): 166-183.

Scott J. Long and Jeremy Freese (2001) Regression Models for Categorical Dependent Variable Using Stata, College Station, TX: Stata Press.

Mugisha, F. and Zulu, E. M. (2004) “The influence of alcohol, drugs and substance abuse on sexual relationships and perception of risk to HIV infection among adolescents in the informal settlements of Nairobi”, Journal of Youth Studies, 7(3): 279-293.

Nakosteen, R.A., and M.A. Zimmer (1980) "Migration and Income: The Question of SelfSelection", Southern Economic Journal 46: 840-851.

Pribesh S. and D. B. Downey (1999) "Why Are Residential and School Moves Associated with Poor School Performance?”, Demography, 36(4): 521-534.

Stark, O. (2003) "Tales of Migration Without Wage Differentials: Individual, Family, and Community Contexts”, ZEF Discussion Papers on Development Policy No. 73, Center for Development Research (ZEF), http://www.zef.de/publications.htm, p. 13.

Todaro M. P. and S. C. Smith (2006) Economic Development, $9^{\text {th }}$ edition. Pearson Addison Wesley.

UN-Habitat (United Nations Human Settlement Programme) (2003) Slums of the World: The face of urban poverty in the new Millenium? Global Urban Observatory: Nairobi.

United Nations (1998). World Urbanization Prospects: The 1996 Revision. New York: United Nations, Department of Economic and Social Affairs, Population Division.

Wooldridge, M. J. (2002) Econometric analysis of cross section and panel data. Cambridge, Massachussets: The MIT press, 752p.

World Bank (2000) Entering the 21st Century: World Development Report 1999/2000. New York: Oxford University Press.

Zulu E. M., A. Konseiga, E. Darteh, and B. Mberu (2006) "Migration and the Urbanization of Poverty in sub-Saharan Africa: The Case of Nairobi City, Kenya”, PAA, Los Angeles. 


\section{APPENDIX}

\begin{tabular}{|c|c|c|c|c|c|}
\hline $\begin{array}{l}\text { Table A1 Descriptive statistics by migration } \\
\text { Variable }\end{array}$ & $\begin{array}{l}\text { atus } \\
\text { Migration } \\
\text { strategy }\end{array}$ & $\mathbf{N}$ & $\begin{array}{l}\% \\
\text { Missing }\end{array}$ & Mean & SD \\
\hline \multirow[t]{2}{*}{ average Years of schooling of the household } & Split & 403 & 0 & 9.26 & 2.43 \\
\hline & Joint & 543 & 0.91 & 7.67 & 2.56 \\
\hline \multirow[t]{2}{*}{ average age of the under 5} & Split & 397 & 1.49 & 2.26 & 1.19 \\
\hline & Joint & 548 & 0 & 2.09 & 1.16 \\
\hline \multirow[t]{2}{*}{ Income activity last month==Yes } & Split & 403 & 0 & 0.98 & 0.14 \\
\hline & Joint & 548 & 0 & 0.98 & 0.13 \\
\hline \multirow[t]{2}{*}{ Religion==Catholic } & Split & 403 & 0 & 0.36 & 0.48 \\
\hline & Joint & 548 & 0 & 0.3 & 0.46 \\
\hline \multirow[t]{2}{*}{ Religion==Protestant } & Split & 403 & 0 & 0.54 & 0.5 \\
\hline & Joint & 548 & 0 & 0.49 & 0.5 \\
\hline \multirow[t]{2}{*}{ Religion==Other Christian } & Split & 403 & 0 & 0.04 & 0.2 \\
\hline & Joint & 548 & 0 & 0.09 & 0.29 \\
\hline \multirow[t]{2}{*}{ Religion==Muslim } & Split & 403 & 0 & 0.02 & 0.13 \\
\hline & Joint & 548 & 0 & 0.05 & 0.21 \\
\hline \multirow[t]{2}{*}{ Religion==No Religion } & Split & 403 & 0 & 0.03 & 0.16 \\
\hline & Joint & 548 & 0 & 0.05 & 0.21 \\
\hline \multirow[t]{2}{*}{ Literate $==$ Yes } & Split & 403 & 0 & 0.98 & 0.15 \\
\hline & Joint & 548 & 0 & 0.98 & 0.13 \\
\hline \multirow[t]{2}{*}{ has lost father in the last 10 years } & Split & 403 & 0 & 0.17 & 0.37 \\
\hline & Joint & 548 & 0 & 0.3 & 0.46 \\
\hline \multirow[t]{2}{*}{ Female household head } & Split & 403 & 0 & 0.01 & 0.12 \\
\hline & Joint & 548 & 0 & 0.09 & 0.28 \\
\hline \multirow[t]{2}{*}{ ethnicity==Luhya } & Split & 403 & 0 & 0.07 & 0.26 \\
\hline & Joint & 548 & 0 & 0.15 & 0.36 \\
\hline \multirow[t]{2}{*}{ Social network from origin community $==0$} & Split & 403 & 0 & 0.11 & 0.32 \\
\hline & Joint & 548 & 0 & 0.14 & 0.35 \\
\hline \multirow[t]{2}{*}{ Social network from origin community $==1-10$} & Split & 403 & 0 & 0.42 & 0.49 \\
\hline & Joint & 548 & 0 & 0.48 & 0.5 \\
\hline \multirow[t]{2}{*}{ Social network from origin community $==11-30$} & Split & 403 & 0 & 0.3 & 0.46 \\
\hline & Joint & 548 & 0 & 0.2 & 0.4 \\
\hline \multirow[t]{2}{*}{ Social network from origin community $==31-50$} & Split & 403 & 0 & 0.07 & 0.26 \\
\hline & Joint & 548 & 0 & 0.08 & 0.27 \\
\hline \multirow[t]{2}{*}{ Social network from origin community $==50+$} & Split & 403 & 0 & 0.08 & 0.28 \\
\hline & Joint & 548 & 0 & 0.08 & 0.27 \\
\hline \multirow[t]{2}{*}{ members in spousal+urban household } & Split & 403 & 0 & 5.7 & 1.98 \\
\hline & Joint & 548 & 0 & 4.61 & 1.69 \\
\hline \multirow[t]{2}{*}{ Own land/houses in Nairobi } & Split & 403 & 0 & 1.83 & 13.34 \\
\hline & Joint & 548 & 0 & 1.04 & 9.7 \\
\hline \multirow[t]{2}{*}{ available agricultural production factor } & Split & 403 & 0 & 8.94 & 66.52 \\
\hline & Joint & 548 & 0 & 6.74 & 65.97 \\
\hline \multirow[t]{2}{*}{ Slum==Nyayo } & Split & 403 & 0 & 0.18 & 0.39 \\
\hline & Joint & 548 & 0 & 0.39 & 0.49 \\
\hline
\end{tabular}


Table A2: Morbidity of slum children in joint/split household

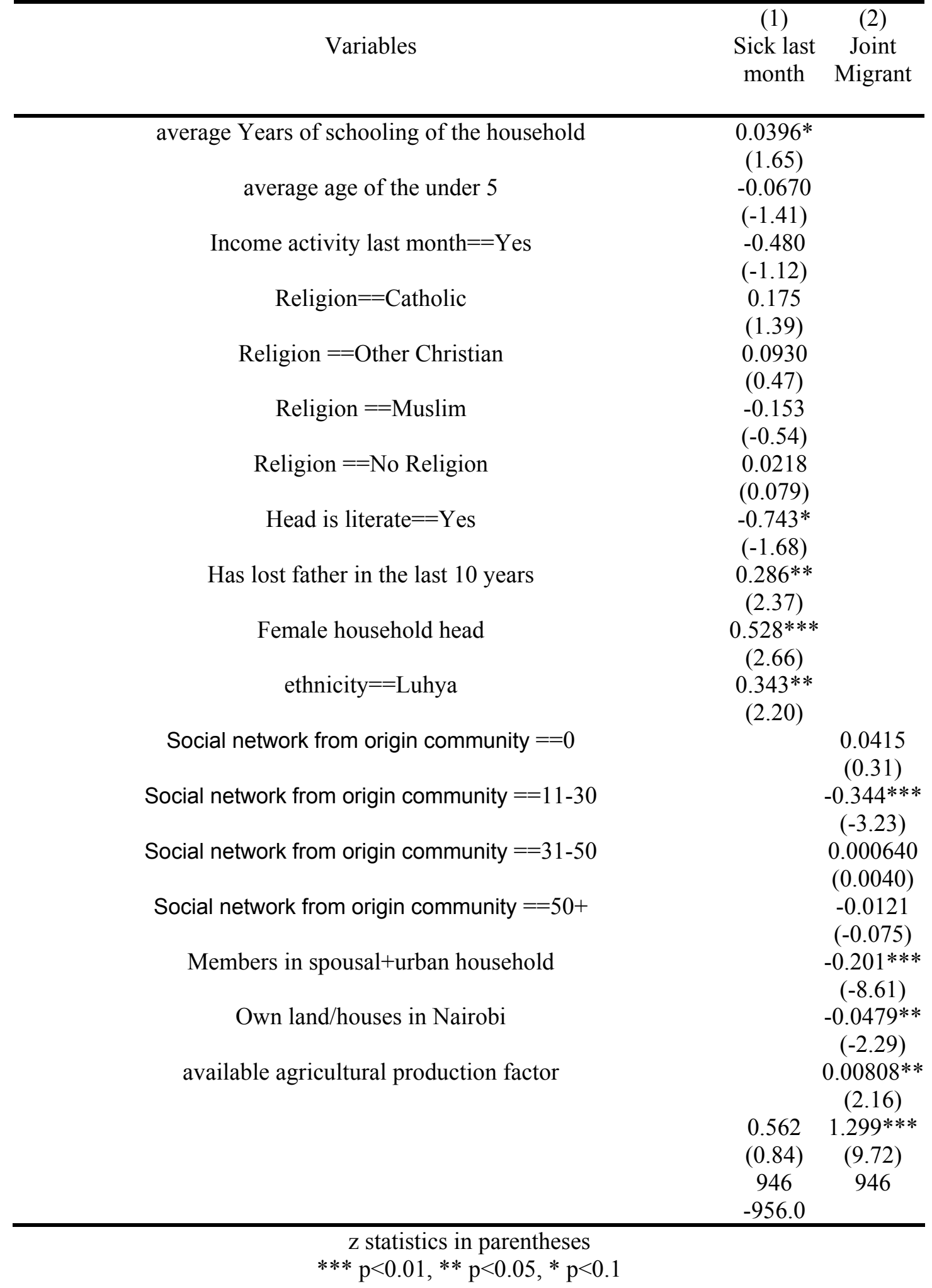


Table A3: Reasons for out-migrating and Destination

\begin{tabular}{lrlllllllll}
\hline & $\begin{array}{l}\text { Marriage } \\
\text { Restination }\end{array}$ & $\begin{array}{l}\text { Housing } \\
\text { Related }\end{array}$ & $\begin{array}{l}\text { Job } \\
\text { Related }\end{array}$ & $\begin{array}{l}\text { Cost } \\
\text { Related }\end{array}$ & $\begin{array}{l}\text { Health } \\
\text { Related }\end{array}$ & Other & Unknown & $\begin{array}{l}\text { Other } \\
\text { family }\end{array}$ & $\begin{array}{l}\text { Family } \\
\text { Relocated }\end{array}$ \\
\hline $\begin{array}{l}\text { Rural } \\
\text { Kenya }\end{array}$ & 241 & 94 & 1,621 & 140 & 168 & 1,260 & 692 & 786 & 507 & 5,509 \\
\hline & 4.37 & 1.71 & 29.42 & 2.54 & 3.05 & 22.87 & 12.56 & 14.27 & 9.2 & 100 \\
\hline
\end{tabular}

Table 3: Reason of in-migration by place of origin

\begin{tabular}{|c|c|c|c|c|c|c|c|c|c|c|}
\hline $\begin{array}{l}\text { Place of } \\
\text { origin }\end{array}$ & $\begin{array}{l}\text { Marriage } \\
\text { related }\end{array}$ & $\begin{array}{l}\text { Housing } \\
\text { Related }\end{array}$ & $\begin{array}{l}\text { Job } \\
\text { Related }\end{array}$ & $\begin{array}{l}\text { Cost } \\
\text { Related }\end{array}$ & $\begin{array}{l}\text { Health } \\
\text { Related }\end{array}$ & Other & Unknown & $\begin{array}{l}\text { Other } \\
\text { family }\end{array}$ & $\begin{array}{l}\text { Family } \\
\text { Relocated }\end{array}$ & Total \\
\hline $\begin{array}{l}\text { Rural } \\
\text { Kenya }\end{array}$ & 1,303 & 90 & 4,181 & 1,179 & 52 & 749 & 371 & 1,528 & 5,062 & 14,515 \\
\hline & 8.98 & 0.62 & 28.8 & 8.12 & 0.36 & 5.16 & 2.56 & 10.53 & 34.87 & 100 \\
\hline
\end{tabular}


Table A4: Treatment Effects on Morbidity of upcountry children

\begin{tabular}{|c|c|c|c|}
\hline & $(1)$ & $(2)$ & $(3)$ \\
\hline Covariates & $\begin{array}{l}\text { Sick last } \\
\text { month }\end{array}$ & Joint migrant & hazard \\
\hline average Years of schooling of the household & $\begin{array}{c}0.0119 * \\
(1.784)\end{array}$ & & \\
\hline average age of the under 5 & $\begin{array}{l}-0.0134 \\
(-1.011)\end{array}$ & & \\
\hline Religion $==$ Protestant & $\begin{array}{c}-0.0546^{*} \\
(-1.739)\end{array}$ & & \\
\hline Urban head is literate $==$ Yes & $\begin{array}{c}-0.315^{* * *} \\
(-2.722)\end{array}$ & & \\
\hline Has lost father in the last 10 years & $\begin{array}{l}0.0526 \\
(1.430)\end{array}$ & & \\
\hline Female household head & $\begin{array}{c}0.163 * * \\
(2.287)\end{array}$ & & \\
\hline Ethnicity==Luhya & $\begin{array}{c}0.119 * * \\
(2.412)\end{array}$ & & \\
\hline Slum $==$ Nyayo & $\begin{array}{c}0.0904 * * \\
(2.490)\end{array}$ & & \\
\hline Married under joint migration & $\begin{array}{l}0.0991 \\
(0.970)\end{array}$ & & \\
\hline Social network from origin community $==0$ & & $\begin{array}{c}0.0361 \\
(0.268)\end{array}$ & \\
\hline Social network from origin community $==11-30$ & & $\begin{array}{c}-0.347 * * * \\
(-3.270)\end{array}$ & \\
\hline Social network from origin community $==31-50$ & & $\begin{array}{l}-0.0166 \\
(-0.103)\end{array}$ & \\
\hline Social network from origin community $==50+$ & & $\begin{array}{l}-0.0333 \\
(-0.208)\end{array}$ & \\
\hline Members in spousal+urban household & & $-0.197 * * *$ & \\
\hline
\end{tabular}


Own land/houses in Nairobi

$(-8.440)$

$-0.0485 * *$

$(-2.343)$

Available agricultural production factors

$0.00819 * *$

(2.229)

Lambda

Constant

$0.534 * * *$

(4.016)

940

$-0.00445$

$(-0.0660)$

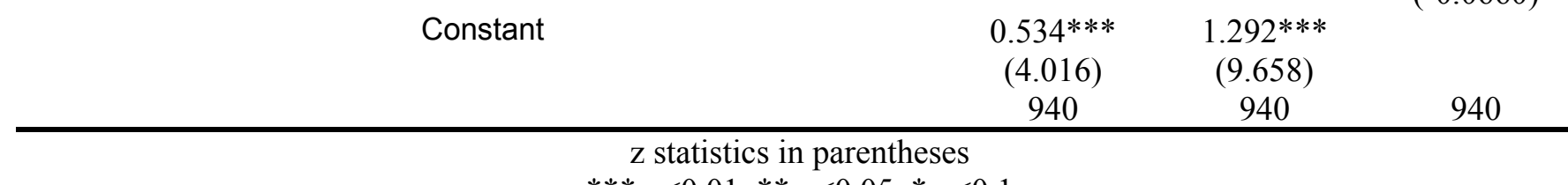

$* * * \mathrm{p}<0.01, * * \mathrm{p}<0.05, * \mathrm{p}<0.1$ 